\title{
An Approach to Samskara in Ayurveda
}

\author{
Review article
}

\author{
Singh Karam ${ }^{1}$, Verma Bhavna ${ }^{2}$ \\ 1. Lecturer, Department of Kaumarbhritya/Balroga \\ 2. Lecturer, Department of Basic Principles, \\ Dayanand Ayurvedic College, Jalandhar, Mahatma Hans Raj Marg, Punjab, 144008 (India).
}

\begin{abstract}
Samskara (Sacraments) are a religious customs (rite), rituals sacrifices a religious ceremony. Samskara also build a wakefulness of the attainment of social status and rights for the individual. In Ayurveda, the word samskara also introduced as "Samskarao hi Gunaantradhyanum" means qualitative improvement is carried out by incorporating the specific qualities. The number of Samskara varies in different Hindu dharma granthas, it is about 16-40, but the applicable Samskara are 16 (shodash) in number which spreads from garbhadan to anteysthi samskara. In the present paper, it can be concluded that the Samskara described in Ayurvedic texts are based on the various milestones of child growth and developments and hence provide a rational guideline toward his care from very conception to adolescence.
\end{abstract}

Keywords: Samskara, Sacraments, milestone, growth and development.

\section{Introduction}

In Hindu culture it is believe that every aspect of life is sacred, so due to this reason each important stage, from conception to anteyeshti (death cremation) is distinguished as special rituals. The Samskaras are performed for the physical, social, and religious development of the individual. The sacrament composed of worships of Gods and words spoken as mantras by the vaidya as per Ayurvedic texts. The sacraments occur at important events and give value to a person's life.

Different meaning of Samskara:-

*Corresponding Author:

\section{Singh Karam,}

H.no: 104, BSF Colony,

Jalandhar City,

Punjab. 144008

Email id-drksverma82@gmail.com

Ph. no- 08427826622, 9794342858
1) Samskara (Sacraments) are a religious customs (rite), rituals and sacrifices a religious ceremony. The life of the performer receives a higher sacredness after performing them, it is believed. In Hindu culture, Samskara cover the entire life of an individual which begins from the moment he is conceived in the mother's womb till his death (compassing of the funeral ceremonies).

2) Sacrament also means conformation of some promise; things of unexplained significance, sacred influence and symbol.

3) The Samskara are a series of sacraments that serve as rites of passage (which is a ritual event that marks a person's progress from one status to another) and mark the various stages of the human life and to signify entry to a particular ashrama. 
4) The word Samskar is derived from root word 'Kri' with 'Sam' upsarga, which is being used for several meanings for example in sense of education, cultivation, and training, a purificatory rite or ceremony to change the qualities or intrinsic worth.

A general definition of samskara, encompassing nearly all of the above is "to improve upon something while removing its undesirable attributes." Samskara or Sacraments give meaning to the teachings of the Vedas and Hindu religion. We need various Samskara from time to time for religious/spiritual motivation during this passage of life. Samskara are rites that are meant to purify and positively influence our lives throughout our growth and development, from conception unitl death. Samskara are religious rites which help direct our lives towards Dharma (righteous living). They help and guide us to higher levels of morality and spirituality.

\section{Objects of the Samskaras}

There are several objects of the Samskaras, as to pray the god for better things in coming days and to eliminate harmful powers that agitated (or trouble) human life at different stages.

1) Samskara aim in the first instance at material gain to the individual. During some ceremonies prayers are offered to gods for health, wealth, children, intellect etc., which contribute to family and social happiness.

2) Samskaras also build a wakefulness of the attainment of social status and rights for the individual.

3) Samskaras bring about cultural gains. The various ceremonies related to the samskaras help in the formation and development of personality.

4) Samskaras convey a higher sacredness to life. Various Impurities associated with the body are cleared by performing samskaras. The samskaras are a form of spiritual endeavour (sadhana) - an external discipline for internal spiritual tutoring.

In Ayurveda, the word samskara also introduced as "Samskarao hi Gunaantradhyanum" means qualitative improvement is carried out by incorporating the specific qualities (in various dravyas or medicines as rasa aushadhi) (Charaka Samhita Vimansthana 1/21, p.680) (1).

\section{NUMBER OF SAMSKARA}

The number of Samskara varies in different Hindu dharma granthas, it is about 16-40, but the applicable Samskara are 16 (shodash) in number (Kaumarbhritya p.123) (2). These are:

1) Garbhadan (Sacrament of Impregnation or Conception)

2) Pumsavana (Engendering a male issue)

3) Simantonayana (Hair-parting)

4) Jatakarma (Birth rituals e.g. at the time when the child is being born)

5) Namakarana (Naming ceremony)

6) Nishkrama (First outing or outing ceremony)

7) Annaprashana (feeding ceremony)

8) Chudakarma or Mundan (Shaving of head)

9) Karnavedhan (Piercing the earlobes)

10) Upanayana (Sacred thread initiation)

11) Vedarambha (Beginning of vedic study)

12) Samavartan (End of studentship)

13) Vivaha (Marriage Ceremony)

14) Vanprastha (Renouncing the householder's life)

15) Sanyyas(Leading the life of a monk)

16) Anteyeshti (Death cremation).

\section{CLASSIFICATION OF SAMSKARA}

1) The samskara can be categorising given above which range from conception (prebirth) to funeral (post-death) ceremonies as:-

a) Garbhastha (Pre-natal) Samskaras:Garbhadan, Pumsavana, Simantoonayana 
b) Balyawasthantargata (Childhood) Samskaras: Jatakarma, Namakarana, Nishkramna,

Annaprashana,

Chudakarma, Karnavedhan.

c) Adhyyanartha (Educational) Samskara: Vidyarambha, Upanayana , Vedarambha

d) Grahasthartha (Marriage) Samskara: Vivaha

e) Death Samskara: Antyeshti.

2) The Samskara in Balyaawastha may be classified as follows-

1. Ksheerap kala: a) During Neonatal Period: Jatakarma, Namkarana. b) During Infantile Period: Nishkramana, Annaprashan/Phalaprashana,

Karnavedhan.

2. Ksheerannad/Annada kala: a) During Toddler Period: Chudkarana Samskara. B) During Preschool and school Age: Upnayana Samskara, Vedarambha Samskara

\section{THESE SAMSKARA ARE AS FOLLOWS:}

\section{(A) PRE-NATAL SAMSKARA}

\section{Garbhadhan (Conception) Samskara:}

This Samskara relates to conception. Procreation is a compulsory duty enjoined on the Hindu to pay back his ancestral debt, except when either or both the partners are functionally unfit. In ayurvedic texts, garbhadhan sacrament elaborated related to environmental factors, specific dietetics and cleansing measures which might influence the reproductive capabilities and have great phsiological and psychological significance. During this ceremony, certain rules which compose do's and donot's are advised like:-

a) Proper age for marriage and first conception (Charaka Samhita Chikitsasthana 2/4/40, p.90 (1), Sushruta Samhita Sutrasthana 35/15
p.132
(3)
Astanga
Hridyum Sharirsthana $1 / 8$ p.339 (4). b) Various results of impregnation in very young or old woman (Charaka Samhita Sharirsthana 8/6 p.920 (1) and Astanga Hyridya Sharirsthana 1/9 p.339 (4).

c) Specific rituals to be permitted by preceptor means putriya vidhi sacrament (Sushruta Samhita Sharirsthana 2/27 p.13 (3) and Astanga Hyridya Sharirsthana 1/27 p.343 (4).

d) The method of performing Putressti yajana (Charaka Samhita Sharirsthana 8/11 p.923(1) and Astanga Hyridya Sharirsthana 1/27 p.343 (4).

e) Effect of psychology of the woman on the foetus (Charaka Samhita Sharirsthana 8/14 p.924 (1), Sushruta Samhita Sharirsthana 2/55 p.18 (3).

The auspicious day and time are fixed for garbhadhana and the sacrament follows a set guide. The articulated mantras represents in this Samskaras are essentially prayers offered to God to help the bride (female) conceive a good son.The significance of this samskara is highly important, as these ceremony purify and refine field (woman'reproductive system) and seed (sperms), thus the born child will posses high qualities.

\section{Punsavan Samskara (Engendering a male issue):}

The term pumsavana literally means 'male procreation'. So, the process which is adopted for achieving progeny of desired sex is known as Punsava karma. This is performed in second month (Charaka Samhita Sharirsthana 8/19 p.926 (1) or before vyaktibhava (Astanga Hyridya Sharirsthana 1/37 p.345 (4). Different acharyas prescribe various formulations for use to pregnant woman which may result to male procreation only, as their belief. According to Charaka (Charaka Samhita Sharirsthana 8/19 p.926 (1), healthy sunga (leaf buds) of banyan tree, dhanyamasha and gaurasarsapa should be taken with curd during Pusyanaksatra. Similarly paste of jivaka, rishbhaka, apamarga and sahachara taken 
with milk etc. According to Sushruta (Sushruta Samhita Sharirsthana 2/35 p.15 (3), description of punsavana given as: pregnant woman instil three or four drops of juice in the right nostril which are Sulakshmana, Batasunga, Sahadevi and Vishvadeva pounded with milk. She should not spit out the juice. Similar description given by Vagbhata (Astanga Hyridya Sharirsthana 1/38-42 p.345 (4). The significance of this Samskara is to invoke celestial (or divine) and excellent qualities in the child.

\section{Simantonayana (Hair-parting):}

a. In this, the husband parts the wife's hair.The time to perform this sacrament have many views, but overall it is performed in fourth to eight month of pregnancy.

b. In Ayurvedic texts during period of pregnancy, acharyas advised monthwise various dietetic regimen and mode of conducts for pregnant woman which results in normal development of foetus who has good health, strength, voice, compactness etc. (Charaka Samhita Sharirsthana 8/32-38 p.937, Sushruta Samhita Sharirsthana 10/2 p.73 (3).

c. Acharya also advised that if mother not follow proper advised lifestyle then it may result in doshas vitiation which produce abnormalities of fetous (garbhang-vikriti), affecting its appearance, complexion and indriyas (sense organ) (Sushruta Samhita Sharirsthana 3/14-15 p.24 (3), Charaka Samhita sharirsthana 2/29-30 p.846 (1), Astanga Hyridya Sharirsthana 1/48 p.346(4).

d. As it is now well known that smoking, alcohol, certain medications and drugs have a detrimental ill-effect on the foetus. So by following this ceremony, husband and family advised to take every possible care to safeguard the physical and mental health of pregnant woman. e. The religious significance of this Samskara is to bring prosperity to the mother and long life to the unborn child.

\section{(B) NEONATAL SAMSKARA}

4. Jatkarma Samskara (ceremony performed after birth or Birth rituals):

According to Charaka, after the cutting of umbilical cord (nalchhedan) the infant's birth rites should be performed. As per acharya Charaka (Charaka Samhita Sharirsthana 8/46 p.950 (1)), on first day of birth, the child should be given first feeding of honey and ghrita consecrated (or blessed) with mantra as given for this purpose. Thereafter, firstly milk from the right breast should be offered (or given) to the child. A water filled pitcher and consecrated with mantras should be kept near the head of baby, probably to maintain proper humidity in Kumaragara. Acharya Sushruta (Sushruta Samhita Sharirsthana 10/15-17 p.76 (3) says that on first day after performing nalachhedan, the child should be sprinkled with cold water and then honey and ghrita mixed with ananta powder in small quantity and sanctified with mantras should be given three times to baby. On second and third day ghrita medicated with lakshmana, on fourth day honey and ghrita in the amount which fills the palm of neonate (savapanitalsamita) given two times as well as offer prang-nevartsatnya (breast milk) to baby. According to Vagbhata (Astanga Hyridya Uttartantra 1/11 p.877 (4), Jatakarma (birth ceremony) should be performed by Prajapatya method.

\section{Importance of Jatakarma samskara:}

1. Rooting and sucking reflex as well as sucking-swallowing-breathing

coordination is assessed while offering honey and ghee.

2.The Jatakarma can also prove an as an efficient tool of examination to rule out oral anomalies such as cleft palate, natal teeth, fissured tongue, ankyloglossia, tracheo-esophageal fistula etc. 
3. Benefit of breast-feeding:

a. Breast feeding at the earliest just after delivery by healthy baby proves beneficial to him and mother. Benefits of breast-feeding include its nutritional (as right amount of Fatty acid, lactose, water and amino acids for human digestion, brain development and growth (5), immunological superiority, antiinfective properties, and benefit to mother as helps uterine involution, reduces postpartum haemorrhage incidence and protection against pregnancy (6) etc.

b. Delayed initiation of breastfeeding (hour to day 7) increases more risk of neonatal mortality (Karen M. Edmond et al. (7).

4. Honey used during this ceremony provide following benefit as:-

a. Madhu has sheet, guru, madhur and kashaya (in rasa), raktapitta and kapha-nasaka as well as chhedan (Charaka Samhita Sutrasthana 27/245 p.554 (1), hridya, tridoshhar etc (Sushruta Samhita Sutrasthana 45/132 p.18o (3).

b. Honey also acts as source of energy because it contains mainly fructose (about 38.5\%) and glucose (about $31.0 \%$ ) as well as vitamins and multiminerals $(8,9)$.

c. Honey has antimicrobial properties (antibacterial activity against coagulase-negative staphylococci (V.M.French et al.) (10).

d. Honey also used in wound dressing (P.C.Molan et.al.) (11).

5. Ghee have following effect on body:

a. According to Charaka, ghee is useful to rasa, shukra dhatus and oja (immunity), pittaanilahara, svravarna-prashadanum (Charaka Samhita Sutrasthana 13/14 p.258 (1).

b. By Sushruta, ghee increases samriti, medha (intellect), kaanti, voice, oja, strength, vishahar, rakshoghan
(Sushruta Samhita Sutrasthana 45/96 p.177 (3).

c. Ghee also has lubricating property. So, results in lubrication of the G.I. tract mucosa.

d. Ghee contains fat soluble vitamins such as A, D and E. It contains saturated fatty acids but of short chain fatty acids.

6. Benefit of use of svarna (Gold):

a. Use of gold (suvara-prashan) increases intellect, digestive and metabolic power, strength, aayusha (provide longevity), increase complexion (varnaya), grahamapahum (Kashyapa Samhita Lehaadhyaya p.4-5 (12).

b. Shudha svarna also said vatashamaka, rasayana, dipan, netrya, medhya etc. (Bhaisajyaratnavali 2/99-100 p.26 (13).

c. Gold compounds have Immunomodulatory effects (C.K Hashimoto et.al. 1992) (14).

7. Jatkarma ceremony is an appropriate opportunity for physicians to encourage maternal confidence through proper guidance and education for better breast feeding practices during infantile period.

\section{Namakarana Samskara (Naming Ceremony):}

A sacrament for imposing of divinity in newly-born human child. Based on the arrangement of the constellations at birth, the child is named on a day fixed by caste tradition. The Namkaran Samskara (Naming Ceremony) of the child is normally performed on the tenth or twelfth day after birth.

In Ayurvedic texts, according to Charaka (Charaka Samhita Sharirsthana $8 / 50$ p.953 (1) on the tenth day, the mother alongwith the baby having taken bath with water containing or medicated with sarvagandha (aromatic) drugs, gaursarspa (white mustard) and lodhra, having wear light, uncontaminated and clear cloth, 
wearing favourable, pleasing, light and fine ornaments. After that she should touch auspicious objects, worship the appropriate god, fire and Brahman who possessing shikha, wear white cloth, without any deformity. After swastikavachana by brahmana, the child should be kept over a bed of new (nutan), unsoiled cloths, she (mother) should sit keeping head of the child towards the east or north. Then the father should say that the child is offering prayer to the god and brahmanas, and then give two names- one Naksatrika and the other Abhiprayika (name for day to day use). It should begin with ghosa-alphabets and middle with antasth (semi-vowel) and end with usma-alphabets. Beside there should not be a letter with vrddha category, in this type of name and be identical with the names of three generation (father, grandfather and great grandfather). The name also should be famous one. The Naksatrika type of name should have similarity to the planet of birth. It should be composed of either two or four letters.

According to Sushruta (Sushruta Samhita Sharirsthana 10/27p.78 (3) on the tenth day parents after performing mangala (auspicious celebrations) and kautuka worships should fix the name of the child according to their wish (abhista) or nakshatra.

Vagabhata (Astanga Hridta Uttaratantra 1/22-23 p.879 (4) stated near about descriptionon as acharya Charaka. The father of child should perform the naming ceremony after tenth day according to tradition of one's family. The woman who has delivered (and also the child) should be given the ritual bath following the traditional customs of the family. The child should be adorned with auspicious marks on the body (forehead) it made form Manohwa, ala, rochana, agru and chandana. Then the father should perform the naming of the child. The name should be respected, benedictory and consists the letters similar to Charaka.

\section{Importance of Namakarana samskara:}

a. A person name is foremost and defining aspect of his identity.

b. It is an important tool for socialisation.

c. The child should be named in a manner that is meaningful and reflects a dignified quality.

d. During this ceremony, education is given to parents and other family members that the child should be given the atmosphere where his/her inherent qualities can be awakened.

e. Name of a baby promotes the healthy psychology, good physical and mental development.

f. Acharya Charaka has described Ayupariksha after naming ceremony, which is deciding the healthy and diseased condition of the baby (Charaka Samhita Sharirsthana 8/51).

g. Starting of late neonatal period.

h. Disappearance of physiological jaundice (15). Persistence of jaundice after tenth day in neonate should be considered serious.

i. Baby regains the birth weight.

j. Umbilical cord falls normally after 5 to 10 days but may take longer (15).

\section{(C) INFANTILE SAMSKARA}

6. Niskramana Samskara (outing ceremony or First outing):

This Samskara is performed when the child is taken out of the home for the first time. According to Kashyapa (Kashyapa Samhita Khilasthana 12/4-5 p.316 (12), in fourth month, baby who having been given bath, adorned, wearing new clean clothes, possessing mustard, honey and Ghrita or Gorochana, he alongwith Dhatri (wet nurse) should be taken out of the house and ready to enter the temple. Thereafter worshiping the Agni (burning fire) with Ghrita and Akshata and then after venerating the Brahmana, God Vishnu, Skanda, Matrikas and other family gods with gandh (fragrances), pushpa (flowers), dhupa (fumigations), mala 
(garlands) etc. gifts and eatable substances and so many other methods; thereafter reciting the Brahmanas and taking their blessings and saluting the Guru, should reenter own house; having entered, the physician should recite the mantra (hymen) for offering prayer.

\section{Importance of Nishkramana:}

1. During bath of baby, it is also good time for check any deformity by vaidya as well as clearing any stress or anxiety of parents related to baby.

2. At forth month age (during this ceremony), following devlopement changes appear in infant: At forth month, infant able to reaching out for objects with both hand (Bidextrous reach), able to rolls over the bed, recognizes the mother and responds to her voice, anticipate the feeds, laugh loudly when talked by someone, responds to sound well, starts cooing, curious and shows interest in surrounding environment, Able to fix eyes on external objects and adaptation to external environment begins (6).

3. Disappearance of grasping reflex (34 months), placing reflex (3-4 month), stepping reflex (3-4 months), rooting reflex (3-4 months), tonic neck (2-6 month), Moro's reflex (3-4month) (16). But persistence of these reflexes indicative of cerebral palsy.

4. At 4 month of age, infants are described as "hatching" socially, becoming interested in a wider world (17).

5. According to Acharya Kashypa (Kashyapa Samhita Sutrasthana 20 p.13 (12), the teeth inseminated in fourth month are weak, decay early and are afflicted with many diseases. It should be diseased and weak.

\section{Karnavedhan Samskara (Piercing the earlobes):}

There are different views about performing this ceremony in Ayurvedic texts:

a. According to Sushruta in $6^{\text {th }}$ or $7^{\text {th }}$ month (Sushruta Samhita Sutrasthana 16/3 p.64-65 (3).

b. According to Vagbhata in $6^{\text {th, }} 7^{\text {th }}, 8^{\text {th }}$ month (Astanga Hyridya Uttaratantra 1/28-32 p.882-883 (4).

c. There is a chapter named "Chudakarniye" in Kashyapa samhita (Kashyapa Samhita Sutrasthana 21 p.15 (12), but there is no reference available about performing this ceremony because chapter is incomplete from beginning.

Procedure:-

According to Sushruta (Sushruta Samhita Sutrasthana 16/3 p.64 (3), In the sixth or seventh month, in fortnight and auspicious tithi (date), Karana, muhurta and naksatra, after reciting auspicious hymns, the child should be placed in the lap of wet-nurse or male attendant engaging and consoling him with toys; then the physician pulling the ear with his left hand should pierce the ear lobe at the naturally designed hole enlightened with the sun's rays (devkrrite chhidra) with his right hand slowly and evenly by needle or awl in case of thin and thick lobes respectively; In male child firstly right ear should be pierced but in female child, first left ear should be pierced and then the pichhuvarti be inserted. Similar procedure mentioned by Vagbhata (Astanga Hyridya Uttaratantra 1/28-32 p.882-83 (4). Details in respective references are discussed. Contraindication of Karnavedha Samskara is ajirna (Indigestion), urge of defecation, excessive hot climate.

\section{Importance of Karnavedhan Samskara:}

a. By Sushruta (Sushruta Samhita Sutrasthana 16/3 p.64 (3), the child's ears are pierced for the purpose of raksha-nimit (protection from diseases) and bhushan-nimit (ornamentation). According to 
Kashyapa (Kashyapa Samhita

Sutrasthana 21 p.15 (12), the experienced and expert physician (vaidya) should pierce the ear of child, for achievement of religion (dharma), desires (kama) and wealth (artha). It seems that this procedure may stimulate the strengthening of immune system in response to injury to the ear lobules which initiate antigen-antibody reaction in early life period.

b. By Sushruta (Sushruta Samhita $\begin{array}{llll}\text { Sutrasthana } & 16 / 5 & \text { p.65 (3) and }\end{array}$ Kashyapa (Kashyapa Samhita Sutrasthana 21 p.15 (12), this procedure must be performed by expert (kushal) surgeon (bhishag), not by unexpert (agyani) vaidya which leads to various complications like fever, manyastambha, hanutambha, karnasula etc.

c. Proper asptic measures and instruments used during procedure e.g. sterile needle, medicated solutions, medicines etc.

d. While piercing the ears, prayers and mantras are offered to God to grant good health and strength to the baby.

e. Appropriate time to examine respective month $(6,7,8$ months) devlopement milestones.

\section{Annaprashana Samskara (First} feeding of solid food or Feeding of cereals):

In $6^{\text {th }}$ month- Phalaprashan is advised by Kashyapa whereas Annaprashan is suggested by Sushruta and Vagbhata. In the $10^{\text {th }}$ month, Annaprashan Samskar is indicated by Kashyapa.

1. According to Sushruta (Sushruta Samhita Sharirsthana 10/54 p.81 (3), the child at the age of six months, should be given food light and hitkar (appropriate wholesome food).

2. Acharya Vagbhata (Astanga Hyridya Uttaratantra 1/39 p.884 (4) advised that solid food should be offered to the child gradually simultaneously with discontinuing breast-milk.

3. Acharya Kashyapa (Kashyapa Samhita Khilasthana 12/15 p.318 (12) has described annaprashana samskara in detail. Here, they advised feeding of various fruits in the sixth month. After eruption of teeth or in tenth month, the feeding of cereals (annaprashan) should be done during auspicious day in prajapatya constellation, after worshipping the gods and brahamanes by cereals with meat and donations. Later Kashyapa (Kashyapa Samhita Khilasthana 12/19-23 p.319 (12) give some yoga for nourishment of growing child as:-

a. Prepare a avleha by combination of old, husk free and well washed sati or sashti rice, mixed with oleaginous substances and salt. The powders of wheat and barley also should be given, according to congeniality.

b. Ushna leha (electuary) cooked with vidanga, lavan, oleaginous substances is beneficial, to the one having diarrhoea, kodo should be mixed.

c. To the one having predominance of Pitta, mrdvika with honey and ghrita should be given, and in predominance of Vata, diet with juice of matulunga and salt.

d. The one knowing desh (place of living), agni (digestive power), strength and period, when ever observes the child as hungry, should give him the food according to congeniality with the gap of one or two periods.

\section{Importance of Annaprashana:-}

1. Fruit juices should be given to the child from sixth month which are source of vitamins especially vitamin $\mathrm{C}$.

2. First meal offer to infant would be easily digested, light and soft as advised by Kashyapa.

3. At age of 6 month, breast milk now not enough to fulfil the requirement of 
growing child. So, it is the accurate time to introduction of supplementary feeding as phalprashan.

4. Breast milk is deficient in iron, viamin A, D, K and calcium (6), so by offering phalprashan and annprashan ceremony at this time with breast milk, we can reduce the deficiency of related essential vitamins. 5. We can examine the six month infant which has following milestone (6): Starts sitting with own support (Sits in tripod fashion), Unidextrous reach, recognizes strangers or develops stranger anxiety, pronounce monosyllables (pa, ba, da etc.), lift the head and chest off the surface with weight bearing on hands, may roll from prone to supine, able to bear most of the weight on legs when holding the child in standing position. Similarly tenth month corresponding milestones may also examine e.g. bisyllables, standing with support, sitting without support, waves bye-bye etc.

6. Primary teeth also start erupted e.g. Central incisors (5-7 month), Lateral incisors (7-11 month, First molars (10-16 month) (17).

7. Similiar to phal/annaprashan introduction in Ayurveda, same principle followed in modern paediatrics as after six month of age weaning (which is the process of gradually introducing a infant to adult diet and withdrawing the supply of its mother's milk) starts as (17):- Offer foods which are soft, easily digestible and avoid foods with high allergenic potential (cow's milk, eggs, fish, nuts, soybeans). For feeding, parents should advise to make use of a cup rather than a bottle. Fluids other than breast milk, formula, and water should be discouraged. Give no more than 4-6 oz/day of fruit juices. Phytate intake should be low to enhance mineral absorption.

8. IMNCI recommendation for breastfeeding and complementary feeding for 6-12 months are given as (6): Breastfeed as often as the child wants. Give at least one katori at a time
of:Mashed roti, rice/bread/biscuit mixed in sweetened undiluted milk Or Mashed roti/rice/bread mixed in thick dal with ghee/oil or khichadi with added oil/ghee.Add cooked vegetables Or Dalid/halwa/kheer prepared in milk or any cereal porridge cooked in milk Or Mashed boiled/ froed potatoes. Offer Banana/biscuit/papaya/cheeko/mango as snacks in between the serving.

\section{(D) SAMSKARA IN PRESCHOOL AND SCHOOL AGE \\ 9. Chudakaram (or Mundan) Samskara:}

This samskara involves shaving the head (of a son). There is a chapter named "Chudakarniye" in Kashyapa Samhita (Kashyapa Samhita Sutrasthana 21 p.14-16 (12), but there is no reference available about chudakarm procedure because chapter is incomplete from beginning. This samskara involves first shaving of the child's hair. According to Sushruta, the cutting of hairs, nail gives lightness, prosperity, courage and happiness (Sushruta Samhita Chikitshasthana 24/73 p.109 (3). Acharya Charaka (Charaka Samhita Sutrasthana 5/100) also gives similar opinion.

\section{Importance of Chudakaram:}

1. Acharya Charaka (Charaka Samhita Sharirsthana 8/51 p.954 (1) described general examination of infant in detail. During examination of skull or cranium, skull without defect, well formed, slightly larger than usual, yet not disproportionate to the body and resembling an open umbrella is deemed favourable.

2. At one year age balaawastha changes to annada awastha (Kashyapa Samhita Khilasthana 3/73 p.246 (12) and according to Sushruta (Sushruta Samhita Sutrasthana 35/34 p.135 (3), ksherrpa changes to ksheerannada at one year, at three year age starts annada stage.

3. Diagnosis of Phakka roga (1 year) made as by acharya Kashyapa 
(Kashyapa Samhita Chikitsasthana, Phakachikitsitum chapter p.139 (12).

4. After shaving of head, the size and shape of the head should be documented carefully for normal or abnormal findings.

5. A tower-head, or oxycephalic skull, suggests premature closure of sutures and is associated with various forms of inherited craniosynostosis.

6. Marked venous distension may be observed during inspection of the scalp for any vein prominence because of increased ICP and thrombosis of the superior sagittal sinus. During scalp examination, inspect any cutaneous abnormalities such as cutis aplasia or abnormal hair whorls as they may suggest an underlying genetic disorder (17).

7. Various neurodevelopmental abnormalities may be revealed by gross evaluation of anthropomorphic aspects of the face.

8. Palpation of scalp carefully may also reveal cranial defects or craniotabes, a peculiar softening of the parietal bone so that gentle pressure produces a sensation similar to indenting a Ping-Pong ball (17).

9. Auscultation of the skull is an important adjunct to a neurologic examination.

10. The anterior fontanel (18) (AF) is the largest fontanel and is placed at the junction of the sagital suture, coronal suture and frontal suture. The anterior fontanelle is not completely closed until about the middle of the second year (between 12 to 18 months of age). Examination of anterior fontanel is useful clinical as excessively large AF and its delayed closure is present in following condition: Malnutrition, Hydrocephalus, Cretinism, Down syndrome, Trisomies 13 and 18, rickets, pituitary dwarf etc. Bulging anterior fontanel is sign of raised intracranial pressure exclude crying infants, hydrocephalus, vitamin A poisoning, Urea cycle enzyme defects, Vitamin D dependent rickets etc.

11. The skull may be unduly small as in microcephaly or generalised craniostenosis, Trisomies 13 and 21, Lissencephaly, cerebral dysgenesis etc. or large in hydrocephalous, hydrocephaly, cerebral gigantism, porencephaly, and intracranial tumors etc (18).

12. At one year infant following milestones developed such as walk without support, mature pincer grasp developed, starts turning pages of book and scribble, playing simple ball game, First molar eruption occurs (16-20 month) (6).

\section{Upanayana (Threading Ceremony) Samskara:}

A detailed procedure is to be followed by the disciple (shishya) on the instructions of his teachers (guru) while starting the study of ayurveda as in Charaka (Charaka Samhita Vimanasthana 8/7-13 p.737-42 (1), Sushruta (Sushruta Samhita Sutrasthana 2 p.8-10 (3) and Kashyapa (Kashyapa Samhita Vimanasthana, Shishoopkramniya chapter p.56-65 (12). This Samskara correlate with pre-school age (3-6 years). Amongst all the Samskara, the upanayana samaskara is considered to be of foremost value. The child enters studentship and a life of perfect discipline which involves brahmacharya (celibacy).

\section{Vedarambha (Beginning Vedic study) Samskara:}

According to acharya Sushruta (Sushruta Samhita Sharirsthana 10/57 p.82 (3) as the child acquires capacity, strength to learn and education should be started. This Samskara correlates with school age (6-12 years age). In this samskara, each 
student, according to his lineage, masters his own branch of the Vedas.

\section{Conclusion}

In the present paper, it can be concluded that the Samskara (Sacraments) are a religious customs (rite), rituals sacrifices a religious ceremony. Samskara described in Ayurvedic texts are based on the various stages of child growth and developments and hence provide a rational guideline toward his care during celebrating different ceremonies from very conception to childhood.

\section{References}

1. Pandit Kashinatha Shastri, Dr. Gorakha Natha Chaturvedi. Charaka Samhita of Agnivesa elaborated 'Vidyotini' Hindi commentary, Part-I (reprint year: 2005) and Part-II (reprint year: 2006), Varanasi: Chaukhambha Bharati Academy, 221001 (India).

2. Devendernath Mishra, Kaumarbhritya, Chaukhamba Sanskrit Prathisthana, Delhi, second edition 2008.

3. Kaviraj Ambikadutta Shastri. Susruta Samhita edited with 'Ayurveda Tattva Sandipika' Hindi commentary, Part-I (reprint year: 2005) and Part-II (reprint year: 2004), II, Varanasi: Chaukhambha Sanskrit Sansthan, Varanasi (India).

4. Brahmanand Tripathi. Astanga Hrdayam of Srimadvagbhata, Edited with 'Nirmala' Hindi Commentary, Delhi: Chaukhamba Sanskrit Pratishthan, Reprint edition 2009.

5. Bhavana Singh. Knowledge, Attitude and Practice of Breast Feeding - A Case Study. University Hospital, Kwame Nkrumah. European Journal of Scientific Research 2010;40(3):404-422.

6. O.P. Ghai, V.K Paul., Arvind Bagga. Ghai Essential Pediatrics. CBS
Publishers \& Distributors Pvt. Ltd., New Delhi, $7^{\text {th }}$ edition, 2009.

7. Karen M.Edmond, Charles Zandoh, Maria A. Quigley, Seeba AmengaEtego, Seth Owusu-Agyei, Betty R. Kirkwood. Delayed breastfeeding initiation increases risk of neonatal mortality. Pediatrics 2006;117, No.3.

8. Amy E. Jeffrey, Carlos M. Echazarreta. Medical uses of honey. Rev Biomed 1996; 7:43-49.

9. Cantarelli, M.A. Pellerano, R.G. Marchevsky, E.J.Camina, J.M. Quality of honey from Argentina: study of chemical composition and trace elements. J. Argent. Chem. Soc. 2008;96(1-2): 33-41.

10. V.M. French, R.A.Cooper and P.C.Molan. The antibacterial activity of honey against coagulase-negative staphylococci. Journal of Antimicrobial Chemotherapy 2005;56 (1): 228-231.

11. P.C.Molan. The evidence supporting the use of honey as a wound dressing. International Journal of Lower Extremity Wounds 2006;5(1):40-54.

12. Pandit Hemraj Sharma, Sri Satyapala Bhisagacharya. Kasyapa Samhita or Vrddhajivakaya Tantra with The Vidyotini Hindi commentary and Hindi translation of Sanskrit introduction, Varanasi: Chaukhambha Sanskrit Sansthan, edition reprint2006.

13. Kaviraj Ambika Dutt Shastri, Rajeshwar Dutt Shastri, editors, Bhaisjyaratnavali, Hindi commentary, Chaukhambha Prakashan, Varanasi (India), edition: reprint, 2012.

14. CK Hashimoto, CE Whitehurst, $T$ Matsubara, K Hirohata, and PE Lipsky. Immunomodulatory effects of therapeutic gold compounds. Gold sodium thiomalate inhibits the activity of $\mathrm{T}$ cell protein kinase. J Clin Invest. 1992; 89(6):1839-1848. 
15. Prof.Meharban Singh. Care of the Newborn. Sagar publications, New Delhi, sixth edition, 2004.

16. Piyush Gupta. Clinical Methods in Pediatrics. CBS publishers, 2009.

17. Robert M.Kliegman, Richard E.Behrman, Hal B Jenson, Bonita
F.Stanton. Nelson Textbook of Pediatrics,. Thomson Press (India) Ltd., $18^{\text {th }}$ Edition, 2008.

18. Meharban Singh. Pediatric clinical methods. Sagar Publications, New Delhi, Repriented 2006. 